\title{
Isolation and Structure Elucidation of Soulatro Coumarin From Stem Bark of Calophyllum soulattri Burm F and In Vivo Antiplasmodial Activity by Using Mice Infected by Plasmodium berghei
}

\author{
Jamilah Abbas $^{1 *}$, Achmad Darmawan ${ }^{1}$ and Syafruddin ${ }^{2}$ \\ ${ }^{1}$ Research Centre for Chemistry, Indonesian Institute of Sciences \\ PUSPIPTEK. Serpong. 15314. Indonesia \\ ${ }^{2}$ Eijkman Institute for Molecular Biology, \\ Diponegoro street no 69, Jakarta 104310. Indonesia
}

\begin{abstract}
The soulatro coumarin compound was isolated and elucidated from the stem bark of Calophyllum soulattri Burm F, the samples were collected from Jayapura Papua Irian Island in Indonesia. Isolation process was done by maceration at room temperature in methanol, than partitioned in a mixture of $n$ hexane-water $(I: I)$, followed by dichloromethane-water $(I: I)$ and ethyl acetate-water (I:I). A portion of ethyl acetate extract was subjected to column chromatography over silica gel packed and eluted with $n$-hexane a gradient of ethyl acetate

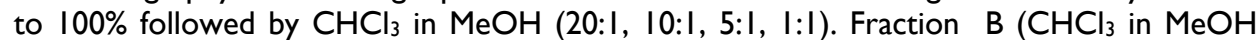
20:I) was subjected to column chromatography over silica gel 300 mesh and eluted with EtOAc-MeOH mixtures of increasing polarity. Faction with the same $R_{f}$ valeus were combined and eluted with EtOAc-MeOH (19:I) showed one spot on TLC. They were combined and evaporated to yield a solid than was recrystallized in mixture of $\mathrm{CH}_{2} \mathrm{Cl}_{2}-$ methanol to give soulatro coumarin compound. The structure was determinated by spectroscopic analysis, in particular by ID and 2D NMR techniques, from these spectra data conclution that compound is soulatro coumarin. Antimalarial assay was tested against Plasmodium berghei parasite as in vivo using 18 mices rodent wich was infected by Plasmodium berghei parasite. The soulatro coumarin showed activity against $P$. berghei with dosage $0.0005867 \mathrm{mM} / \mathrm{l} \mathrm{kg}$ body weight ; $0.005867 \mathrm{mM} / \mathrm{l} \mathrm{kg}$ bw; $0.05867 \mathrm{mM} / \mathrm{l} \mathrm{kg}$ bw; 0.5867 $\mathrm{mM} / \mathrm{l} \mathrm{kg}$ bw $5.867 \mathrm{mM} / \mathrm{l} \mathrm{kg}$ bw and $58.67 \mathrm{mM} / \mathrm{l} \mathrm{kg}$ bw could inhibite growth rate of parasite $=57.32 \% ; 63.37 \% ; 43.02 \% ; 53.49 \% ; 47.67 \%$ respectively.
\end{abstract}

Keywords: Antiplasmodial activity, coumarin, Calophyllum soulattri Burm. F, in vivo, Chloroquine, Plasmodium berghei.

\section{INTRODUCTION}

Calophyllum soulattri Burm F [(local name: Sulatri (Sunda), slatri (Java), malangmalang (Bangka)]. Vernacular Name : bintagor labu (Malaysia). Bintagor lanchar, mintak (Peninsular). C. soulattri is a wide spread but in many places rather uncommon tree of fairly small dimentions, growing in lowland or lower montane rain forest or sometimes in swamp forest, up to $1700 \mathrm{~m}$ altitute. (Soerianegara $e t$ al., 1994). C. soulattri distributed in West Java, Central Java, Irian and Kalimantan Island and also distributed in Vietnam, Cambodia, Thailand,
Andaman, Solomon Island, Northern Australia and Malaysia (Suryanegara et al., 1994). In these research the stem bark of $C$. soulattri Burm F (Guttiferae Family) was used and collected from Jaya Pura (Irian Island) in Indonesia.

The bark, roots and latex of $C$. soulattri are used in local as folk medicine. The fruits are edible but sour. The latex may be used to poison dogs.

*Corresponding author email: jamilahabbas@yahoo.com 
A number of medicinal and therapeutic properties have been described to various parts of $C$. soulattri, e.i root and leaves, including the treatment of rheumatism, varicose veins, hemorrhoids and chronic ulcers (Crane et al., 2005).

Root and leaves of $C$. soulattri also used as rheumatic pain. Seed or other species are used for scabies, ringworm, as an analgesic in leprosy, dermatoses, as diuretic, gonorrhea, tumors, migraine and vertigo (Crane et al., 2005). In the Bulolo area in Papua New Guinea (PNG) the plant used for several diseases, such as dry skin, high blood pressure and malaria (Khan et al., 2002). The balsem from the bark of Calophyllum sp used as a cicatrisan, infusion or decoction of the leaves has been traditionally used as an eye remedy in Asian (Iinuma et al., 1993). Prenylated xanthones have been reported to show antibacterial and antifungal activities (Dharmaratne et al., 1997). The anticancer activity of new coumarin was also investigated against HeLa cell line and the new coumarin showed the most potent as anticancer (Abbas, 2008).

We now report the isolation, structural elucidation and evaluation of the antiplasmodial activity of natural soulatro coumarin isolated from $C$. soulattri, in vivo evaluation of the antiplasmodial activity has been done by using mice which it's infected by Plasmodium berghei.

The Genus Calophyllum is well known as a source of biologically active compound such us xanthones (Reye-Chipa et al., 1997; Kijjoa et al., 2000; Limuna, M et al., 1993), terpenoids (Cao et al., 1998), neoflavonoid (Dharmaratne et al., 1984). Coumarin (Guilet et al., 2001 and Ito et al., 2003). Xanthones, terpenoides, neoflavonoid were found in related species.

Kalazeyloxanthone has been isolated from the root bark of $C$. soulattri by Dharmaratne (Dharmaratne et al. at 1984) (Fig.1)<smiles>CC1=CC2c3c(ccc4oc5cc(O)cc(O)c5c(=O)c34)OC(C)(C)C2CC1</smiles><smiles>CC(C)=CCc1c2c(c(O)c3c(=O)c4c(CC=C(C)C)c(O)ccc4oc13)C=CC(C)(C)O2</smiles>

Figure 2.Structure of dombakinaxanthone
Dombakinaxanthone (diprenylated chromenxanthone) has been isolated from the cold hexane extract of the root bark of $C$. soulattri (Dharmaratne et al., 1993) (Fig. 2). Jayapuracoumarin has also been isolated from stem bark of $C$. soulattri that Jayapuracoumarin has antioxidant and antiplasmodial acrivity (Abbas et al., 2009) (Fig. 3). One new coumarin (aziz coumarin) has also been isolated from stem bark of other species of Calophyllum, that coumarin has antimalarial and cytotoxic acrivity (Abbas et al., 2009) (Fig. 4). One kalocoumarin (brasimarin C) have also success isolated from $C$ incrasaptum, that kalocoumarin has antimalarial activity too (Abbas et al., 2009) (Fig. 5). 
<smiles>C=C(C)C(=O)CCC(C)C</smiles>

Figure 3. Structure of Jayapuracoumarin Structure of kalocoumarin<smiles>COc1ccc2c(c1)OC(=O)C(C)C(C)O2</smiles>

Figure 4. Structures of new coumarin (Aziz coumarin)

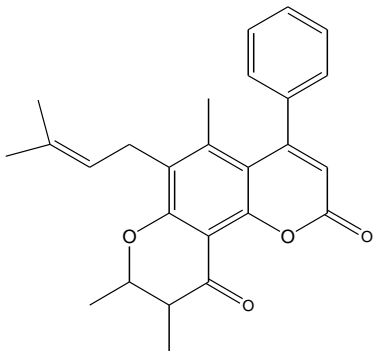

Figure 5.

(Brasimarin C)
Three coumarin (teysmanone A, teysmanone $\mathrm{B}$, calanone) and two coumarin (iophyllum $\mathrm{C}$ and iophyllum $\mathrm{D}$ ) have been isolated from $C$ teysmannii and $\mathrm{C}$ inophyllum respectively (Cao 1998) ). Two soulatro coumarine (pyranocoumarin) has been previously reported from stem bark and leaves of C. soulattri by Samarawera (1983), and one coumarin (soulatrolide) has also been isolated from stem bark of $C$ soulattri (Fig.6).<smiles>CC1(C)CC(=O)c2c(c(C(=O)c3ccccc3)c3oc(=O)cc(-c4ccccc4)c3c2O)O1</smiles>

Teysmanone A<smiles>COc1c(CC=C(C)C)c2c(c3oc(=O)cc(-c4ccccc4)c13)C(=O)[C@H](C)[C@@H](C)O2</smiles>

Teysmanone B<smiles>CC1(C)C=Cc2c(O)c(C(=O)c3ccccc3)c3oc(=O)cc(-c4ccccc4)c3c2O1</smiles>

Calanone<smiles>CC1C(=O)c2c(c3c(c4c(-c5ccccc5)cc(=O)oc24)OC(C)(C)C=C3)O[C@@H]1C</smiles>

Inophyllum C<smiles></smiles>

Inophyllum E

Figure 6. Structures of some coumarins (Teysmanoe A,B, Calanone, Inophyllum C and Inophyllum

D

Two

soulatro

coumarine (pyranocoumarin) has been previously reported from stem bark and leaves of $C$. soulattri by
Samarawera (1983) and one coumarin (soulatrolide) has been isolated from stem bark of C. soulattri. (Fig.7). 


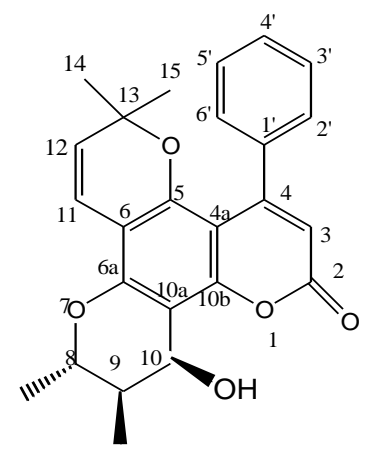

Figure 7. Structure of soulatrolide from C. Soulattri

Other author were repoted soulatro coumarin as anticancer (Cao 1998a), anti HIV (Gustafon, 1994) and three new coumarins also has cancer chemopreventive activity (Ito et al., 2003). In this communication, we report the isolation and structure elucidation of a soulatro coumarin from stem bark of $C$. soulattri as antiplasmodial. $C$. soulattri was choised as a source of antiplasmodial drug candidate, because $C$. soulattri content some coumarin compounds, and according to some refferences, coumarin have antiplasmodial activity. Resistance of plasmodium to antimalarial drugs and their toxicity are contributing factors to the spread of the disease. This highlights the need to develop quickly more effective and less toxic new antimalarial drugs from $C$. soulattri. The isolation of soulatro coumarin will be explained in the experimental procedures.

\section{MATERIALS AND METHODS}

\section{General Experimental Procedures}

Melting point was measured on a Fisher Scientific serial 903N0056 apparatus. UV spectra was measuered on a Hitachi UV-VIS spectrophotometer using methanol solution, $\lambda_{\max }$ in $\mathrm{nm}$ : IR spectra were measured on a FTIR Shimadzu Prestige 21 as KBr disc ; $v$ in $\mathrm{cm}^{-1} .{ }^{13}$ CNMR (150 MHz), ${ }^{1}$ HNMR (500 $\mathrm{MHz}$ ), and 2D NMR experiment (COSY, HMBC, HMQC) spectra were recorded on a Jeol - JNM ECA $500 \mathrm{MHz}$ spectrophotometer, $\mathrm{CDCl}_{3}$ was used as solvents, TMS as internal standar : $\partial$ in ppm, $J$ in $\mathrm{Hz}$. Mass spectrometry analysis was performed on a Mariner Bio Spectrometry, equipped with a pneumatically assisted elecrospray ionization (ESI) source. Silica gel (Merck 200 mesh and 300 mesh) were used for column chromatography. Precoated silica gel at alluminium plates (silica gel $60 \mathrm{~F}_{254}$ ) were used for analytical TLC. Spot were visualized by UV (254 and $365 \mathrm{~nm}$ ), $\mathrm{FeCl}_{3}$ and $10 \% \mathrm{H}_{2} \mathrm{SO}_{4}$ were used as spraying reagent followed by heating at $110^{\circ} \mathrm{C}$.

\section{Plant Material}

The stem bark of $C$. soulattri was colected from Irian Island, Indonesia and the voucher specimen was identified and deposited at the Herbarium Bogorience - LIPI. Bogor, Indonesia.

\section{Extraction and Isolation of Plant Materials}

The dried and powdered of the stem bark of C. soulattri $(1 \mathrm{~kg})$ was maserated by methanol ( $3 \times 2$ litre $\times 7$ days), solvent was removed under reduced pressured by rotary evaporator to gave 109,47 g methanol extract, which was then suspended in water and partitioned with $n$-hexane, dichloromethane and ethyl acetate. Each solvent were removed under pressure by rotary evaporator to give $n$-hexane extract (38.39 g, 3.84\%), dichloromethane extract $(25.05 \mathrm{~g}, 2.51 \%)$ and ethyl acetate extract ( $25 \mathrm{~g}, 2.50 \%)$.

The ethyl acetate extract ( $25 \mathrm{~g})$ was separated by column chromatography on silica gel 70-230 mesh (Merck $800 \mathrm{~g}$ ) by using nhexane a gradient of ethyl acetat to $100 \%$ followed by $\mathrm{CHCl}_{3}$ in $\mathrm{MeOH}(20: 1,10: 1,5: 1$, 1:1). Frction $\mathrm{B}$ from $\left(\mathrm{CHCl}_{3}\right.$ in $\left.\mathrm{MeOH} 20: 1\right)$ was subjected to column chromatography (60 $\mathrm{cm} \times 6 \mathrm{~cm}$ i.d) on silica gel 300 mesh (Merck code 1.07734) eluting by EtOAc : $\mathrm{MeOH}$ with a step gradien elution). Faction with the same $\mathrm{R}_{\mathrm{f}}$ valeus were combined and eluted with EtOAc-MeOH (19:1) and showed one spot on 
TLC than was recrystalized by using $\mathrm{CH}_{2} \mathrm{Cl}_{2}$ and methanol, to produce coumarin compound $(500 \mathrm{mg})$ as pale yellow powder with $\mathrm{mp}$ 83$84^{\circ} \mathrm{C}$ (from fraction 7a). Moleculer weight 426.11 Identically by comparison of ${ }^{1} \mathrm{H}-\mathrm{NMR}$, ${ }^{13} \mathrm{C}$-NMR and MS data with literature values (Cao et al. 1998b)

\section{Determination of the Antimalarial Activity. (Trager and Jensen, 1976 and Fotie et al.,2003) \\ $P$. berghei was maintained continuously} in culture on human erythrocytes as described by Trager and Jensen (Trager and Jensen, 1976). Antimalarial activity of the soulatro coumarin compound was determinated in vivo. In brief soulatro coumarin $2,5 \mathrm{mg}$ (BW 426,11) was dissolved in $100 \mu \mathrm{l}$ DMSO to give 58,670 $\mathrm{mM}$ as stock solution and kept at $-20^{\circ} \mathrm{C}$ until used. The DMSO concentration never exceeded $0.1 \%$ and did not inhibit the parasite growth (Fotie, 2004). Antimalarial activity was done in-vivo against $P$. berghei using mice strain Swiss, Groups of 18 mice strain Swiss, weighing 20-24 g (2-3 month old) were used. The animals had free access to standard commercial diet and water ad libitum in a 12 $\mathrm{h} / 12 \mathrm{~h}$ light-dark cycle at $22^{\circ} \mathrm{C}$ and must be aclimation by giving antibiotic for 3 days before be used. Mice were injected by $100 \mu 1$ P.bergei parasite (pi), inoculaton for 10-14 days, take blood from the vena of mice's tail after 2 days, calculated amount of parasite, if total amaunt of parasites in the mice blood under $20 \%$, take blood from the vena of mice's tail after 3 or 4 or 5 or 6 or 10 days inoculation, calculated amount of parasite, if total of parasite in the mice blood up to $20 \%$, its mean those mices was positive infected by P.berghei parasite, than all mice already be used for antipasmodial evaluation. Inject six dosages of soulatro coumarins to the mice each $100 \mu 1: 0.0005867 \mathrm{mM} / \mathrm{kg}$ body weight: $0.005867 \mathrm{mM} / / \mathrm{kg}$ body weigh; 0.05867 $\mathrm{mM} / / \mathrm{kg}$ body weight; $0.5867 \mathrm{mM} / \mathrm{kg}$ body weight, $5.867 \mathrm{mM} / / \mathrm{kg}$ body weight and 58.670 $\mathrm{mM} / / \mathrm{kg}$ body weight. Take blood from the vena of mice's tail after zero day (D0), one day (D1), two days (D2), three days (D3) and four days (D4) inoculation, were then calculated \% parasites by making a blood smear, fixed with methanol and stained with Giemsa stain. Number of the infected red blood cells were counted under the microscope. Injected the chloroquine to the mice $2,5 \mathrm{mg} / \mathrm{kg}$ body weight, cloroquine was used as a positive control.

The concentration response parasite growth data were analyzed by a linear regression function using the Sigma-plot 2000 computer program to determine the $50 \%$ inhibitory concentration $\left(\mathrm{IC}_{50}\right)$. The $\mathrm{IC}_{50}$ value is defined as the concentration of compound producing $50 \%$ parasite growth inhibition relative to untreated control (without give the soulatro coumarins sample)

\section{RESULTS AND DISCUSSION}

Coumarin compound gave a positive reaction with $\mathrm{FeCl}_{3}$ reagent in methanol (-blue spot) (that mean coumarin contain $\mathrm{OH}$ groups, the $\mathrm{OH}$ with $\mathrm{FeCl}_{3}$ become $\mathrm{Fe}(\mathrm{OH})_{3}$ blue spot. This structure was established by spectroscopic means. In the LC-MS spectrum (Fig. 11), showed the moleculer ion $(\mathrm{M}+1)^{+}$at $\mathrm{m} / \mathrm{z}=$ 427.11 and moleculer ion $(2 \mathrm{M})^{+}$at $\mathrm{m} / \mathrm{z}=$ 852.48 and also $(2 \mathrm{M}+\mathrm{Na})^{+}$at $\mathrm{m} / \mathrm{z}=874.48$, corresponding to the molecular formula of $\mathrm{C}_{25} \mathrm{H}_{30} \mathrm{O}_{6}$ and moleculer weigh 426.11 (Fig. $8 \mathrm{c})$. 


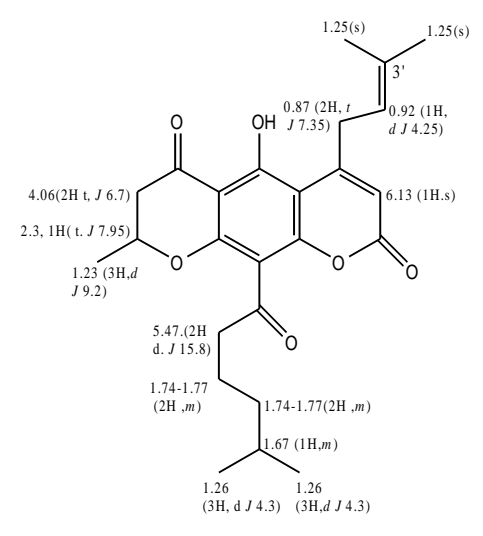

$$
\begin{aligned}
& \mathrm{C}_{25} \mathrm{H}_{30} \mathrm{O}_{6} \\
& \mathrm{BM}=426
\end{aligned}
$$

Figure 8a, 'H- NMR Chemical shift of soulatro coumarin<smiles>CC(C)=CCc1cc(=O)oc2c(C(=O)CCCC(C)C)c3c(c(O)c12)C(=O)CC(C)O3</smiles>

$$
\begin{aligned}
& \mathrm{C}_{25} \mathrm{H}_{30} \mathrm{O}_{6} \\
& \mathrm{BM}=426
\end{aligned}
$$

Figure 8c. Structure of soulatro coumarin

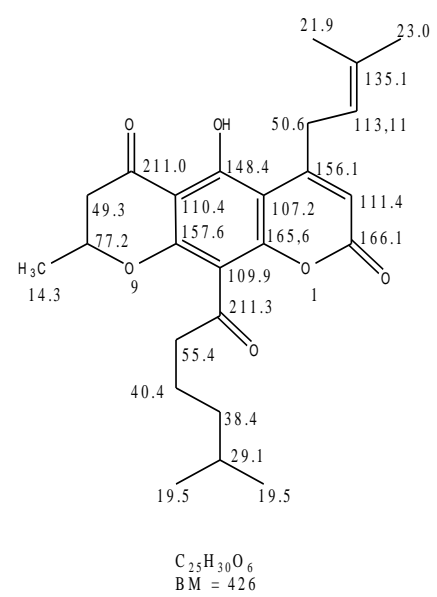

Figure 8b. ${ }^{13} \mathrm{C}-\mathrm{NMR}$ Chemical Shift of soulatro coumarin

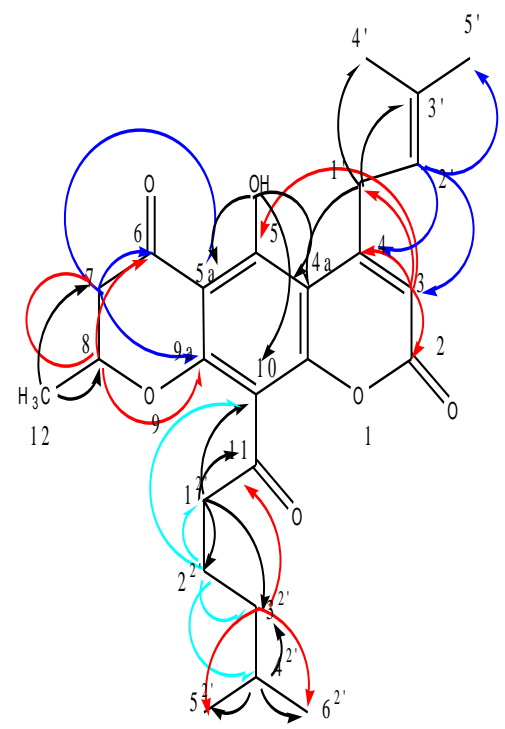

$\mathrm{C}_{25} \mathrm{H}_{30} \mathrm{O}_{6}$ $B M=426$

Figure 9. HMBC correlation of new soulatro coumarin 
Table I. 'H and ${ }^{13} \mathrm{C}$ NMR spectral data for soulatro coumarin

\begin{tabular}{|c|c|c|c|}
\hline Carbon & ${ }^{13} \mathrm{C}-\mathrm{NMR}$ & IH-NMR & HMBC correlation \\
\hline 1 & & & \\
\hline 2 & 166.1 & & \\
\hline 3 & 111.4 & $6.13(1 \mathrm{H}, \mathrm{s})$ & C-2, C-4, C-I' \\
\hline 4 & I56.| & & \\
\hline $4 a$ & 107.2 & & \\
\hline 5 & 148.4 & & \\
\hline $5 a$ & 110.4 & & \\
\hline 6 & 211.0 & & \\
\hline 7 & 49.3 & $4.06(2 \mathrm{H}, t J=6.7)$ & $C-5 a, C-6, C-9 a$ \\
\hline 8 & 77.2 & $2.34(\mathrm{IH}, t J=7.95)$ & C-7, C-6, C-9a \\
\hline 9 & - & - & - \\
\hline $9 a$ & 157.6 & & \\
\hline 10 & 109.9 & & \\
\hline $10 \mathrm{a}$ & 165.6 & & \\
\hline $\mathrm{II}$ & 211.3 & & \\
\hline 12 & 14,3 & $\mathrm{I}, 23(3 \mathrm{H}, d J=9,25)$ & C-7, C-8 \\
\hline I' & 50.6 & $0.92(2 \mathrm{H}, \mathrm{dJ}=4.25)$ & C-3', C-4', C-4a \\
\hline 2' & 113.10 & $0.87(\mathrm{IH}, t \mathrm{~J}=7.35)$ & $C-3, C-4, C-5$ \\
\hline 3 ' & 135.1 & - & \\
\hline $4^{\prime}$ & 21.9 & $1.25(3 \mathrm{H}, \mathrm{s})$ & C-I',C-2', \\
\hline $5^{\prime}$ & 23.0 & $1.25(3 \mathrm{H}, \mathrm{s})$ & C-I',C-2', \\
\hline $12^{\prime}$ & 55.4 & $5.47(2 \mathrm{H}, \mathrm{d} J=I 5.8)$ & C-10, C-II, C-22'- C-32'- \\
\hline $2^{2}$ & 40.4 & I.74-I.77 $(2 \mathrm{H}, m)$ & $C-10, C-12^{\prime}-C-32^{\prime}, C-42^{\prime}-$ \\
\hline $32^{\prime}$ & 38.4 & I.74-I.77 $(2 \mathrm{H}, \mathrm{m})$ & $C-11, C-12^{2}-C-5^{2}, C-62^{2}-$ \\
\hline $42^{\prime}$ & 29.1 & $\mathrm{I} .67(\mathrm{IH}, \mathrm{m})$ & C-32'- C- $-2^{2}$, C- $62^{\prime}-$ \\
\hline $5^{\prime}$ & 19.5 & $1.26(3 \mathrm{H}, d,=4.3)$ & $C-42^{\prime}-C-32^{\prime}, C-2^{2}-$ \\
\hline $6^{2}$ & 19.5 & $1.26(3 \mathrm{H}, \mathrm{d}, \mathrm{J}=4.3)$ & $C-42^{\prime}-C-32^{\prime}, C-2^{2}-$ \\
\hline
\end{tabular}

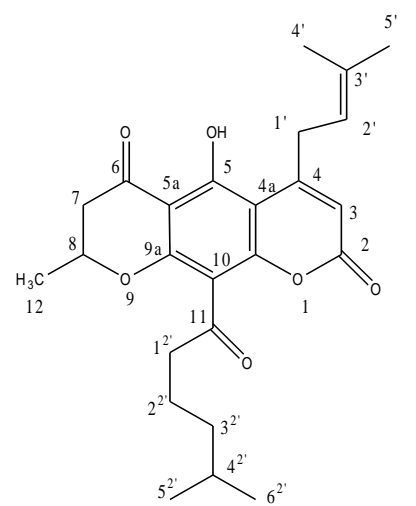

(A)

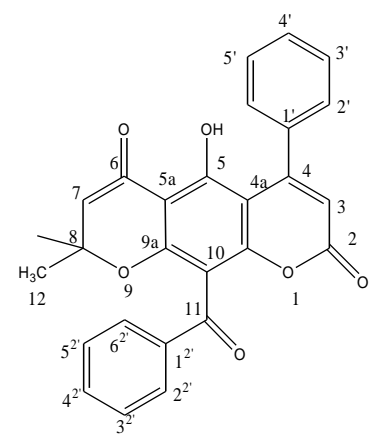

(B)

Figure 10. Sructure of Soulatro coumarin and teysmanone. (A) Soulatro coumarin from stem bark C. soulattri, (B) Coumarin (teysmanone) from refference (Cao 1998) 
Table II. Differenties of ${ }^{13} \mathrm{C}$ NMR spectral data of new soulatro coumarin and other coumarin (teysmanone Cao 1998b)

\begin{tabular}{|c|c|c|}
\hline Carbon & $\begin{array}{c}{ }^{13} \text { C-NMR } \\
\text { new coumarin } \\
\text { (Soulatro coumarin) }\end{array}$ & $\begin{array}{c}\text { 13C-NMR } \\
\text { Coumarin (teysmanone) } \\
\text { (Reffence, Cao 1998) }\end{array}$ \\
\hline $\mathrm{I}$ & - & - \\
\hline 2 & 166.1 & 158,9 \\
\hline 3 & $1 \mid 1.4$ & 113.1 \\
\hline 4 & 156.1 & 152.5 \\
\hline $4 a$ & 107.2 & 101.1 \\
\hline 5 & 148.4 & 149.9 \\
\hline $5 a$ & 110.4 & 106.3 \\
\hline 6 & 211.0 & 115.4 \\
\hline 7 & 49.3 & 47,2 \\
\hline 8 & 77.2 & 79,5 \\
\hline 9 & - & - \\
\hline $9 a$ & 157.6 & 157.6 \\
\hline 10 & 109.9 & 109.9 \\
\hline $10 \mathrm{a}$ & 165.6 & 106,4 \\
\hline 11 & 211.3 & 191.9 \\
\hline 12 & 14,3 & 28.0 \\
\hline I' & 50.6 & 135.9 \\
\hline 2 & 113.10 & 127.5 \\
\hline 3 & 135.1 & 130.1 \\
\hline 4 ' & 21.9 & 130.6 \\
\hline 5 & 23.0 & 130.1 \\
\hline $1^{2}$ & 55.4 & 137.6 \\
\hline $2^{2}$ & 40.4 & 129.6 \\
\hline $3^{2}$ & 38.4 & 128,5 \\
\hline $42^{\prime}$ & 29.1 & 135.3 \\
\hline $5^{\prime}$ & 19.5 & 128.5 \\
\hline $6^{2}$ & 19.5 & 129.6 \\
\hline
\end{tabular}

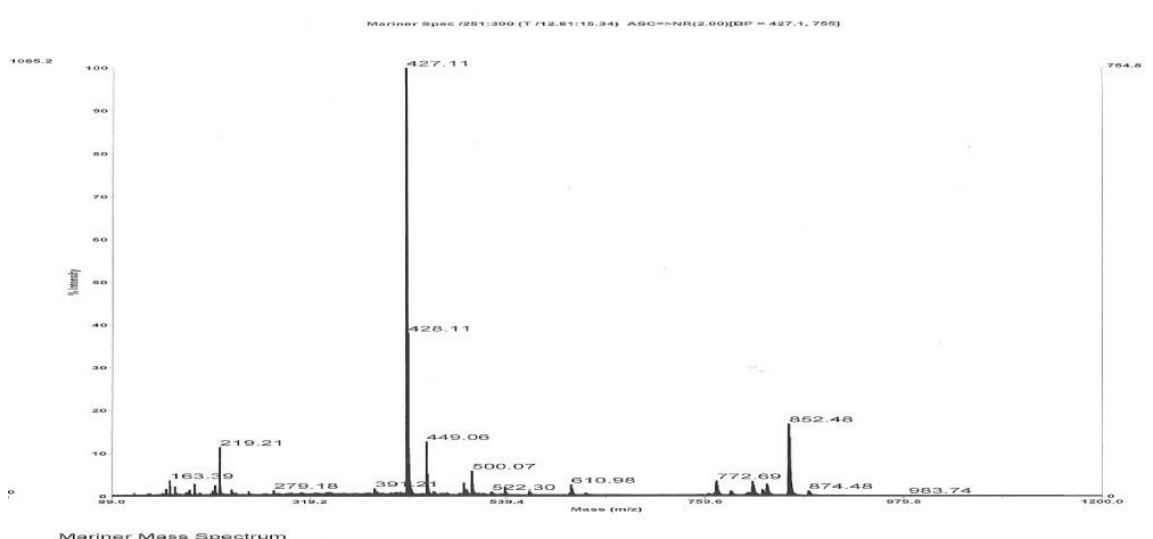

Figure II. LC-MS spectra of soulatro coumarin compound (Column CI 8 with $80 \%$ methanol-water as eluent)

In the IR spectrum, a absorption bands attributable to an $\mathrm{OH}$ (3352 $\mathrm{cm}^{-1}$ sharp) and $\mathrm{C}=\mathrm{O}$ groups from nucleus coumarin $(1697$ and $1390 \mathrm{~cm}^{-1}$ for $\left.\mathrm{C}-\mathrm{O}\right)$, aromatic ring $(\mathrm{C}=\mathrm{C})$ at
1604 and $1558 \mathrm{~cm}^{-1}$ and $\mathrm{C}-\mathrm{H}$ streching methyl group at 2964 and $2872 \mathrm{~cm}^{-1}$ and C-H bending methyl at 850, 889 and $933 \mathrm{~cm}^{-1}$ (Fig. 12). 


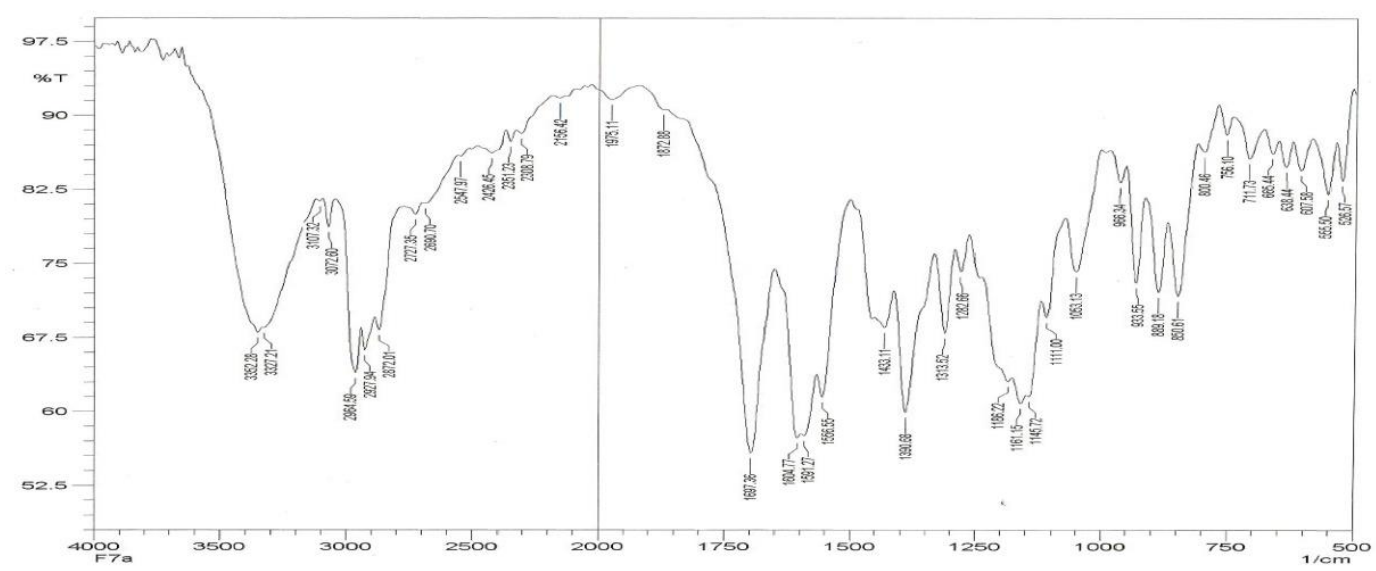

Figure I2. IR spectra of soulatro coumarin compound in $\mathrm{KBr}$ pellet

UV absorption maximum at $\lambda 221.5 \mathrm{~nm}$ with absorbance 0.394 typical of an oxygenated coumarin and at $\lambda 257.0$ with absorban 0.205 and at $\lambda 331.0 \mathrm{~nm}$ with absorban 0.590 (C 10 $\mathrm{ppm}$ in methanol). These UV spectrum showed the typical absorptions of a prenylcoumarin nucleus at $\lambda_{\max }=221.5$.; 257.0 and $331.0 \mathrm{~nm}$ (Fig. 13). UV spectra of soulatro coumarin compounds is similier with Reff $\left(\lambda_{\max } 228 \&\right.$ 286 and $324 \mathrm{~nm}$, Cao 1998 $8^{\mathrm{b}}$, Ito et al., 2003) .

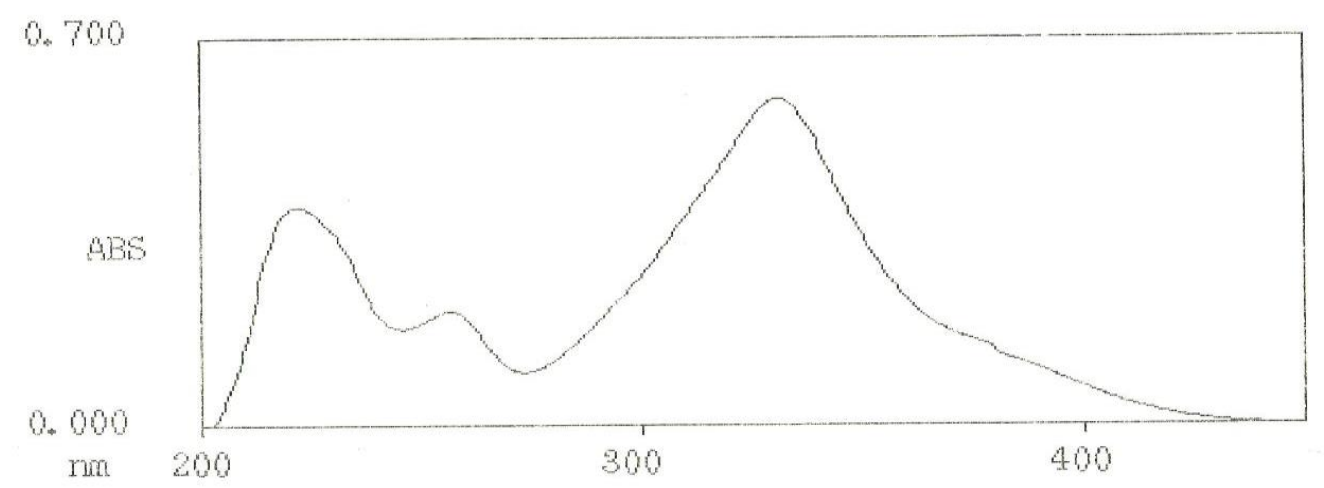

Figure 13. UV spectra of soulatro coumarin compound in methanol as solvent

The ${ }^{1} \mathrm{H}-\mathrm{NMR}$ spectrum $(500 \mathrm{MHz}$ in $\mathrm{CDCl}_{3}$ ) revealed signal assign able to a prenyl group at $\mathrm{C}-4$, and additional one proton siglet at $\delta 6.13(1 \mathrm{H}, s)$ spesific at posistion C-3. Proton siglet at $\delta 6.13$ corelated to the $\mathrm{C}$-atom at $\delta 111,4$ in the HMQC spectrum, The HMBC spectrum proton siglet at $\delta 6.13$ showed longrange correlation to $\mathrm{C}$-signals at $\delta 165,6$ (C10a), 156,1 (C-4), 148,4 (C-5) and 50,6 (C-1'). The C-atom at 50,6 (C-1') was also correlated to the aliphatic proton at C-3', C-4' and C-5', The corelation between proton at $\mathrm{C}-3$ and carbon at C-2, C-4, C-1' and C-2') allowed the position of prenyl group at $\mathrm{C}(4)$ (Table I and Fig. 10) which confirmed that the isoprenyl group was attached at $\mathrm{C}-4$ of the coumarin moiety

HMBC-2D data illustrate the existence of a single isoprenyl group substitution at position C-4 and one hydroxyl at position C-5 and one carbonyl at C-6, that new compound were given name soulatro coumarin. The ${ }^{1} \mathrm{H}$ NMR and ${ }^{13} \mathrm{C}$-NMR spectral data of new soulatro coumarin as in Table I, Fig. $8 \mathrm{a}$ and $8 \mathrm{~b}$. The structure of the new soulatro coumarin was showed in Fig. 8c and HMBC correlation of a new soulatro coumarin was showed in Fig. 9.

The ${ }^{13} \mathrm{C}$-NMR spectrum revealed an aliphatic ketone $(\delta 211.3)$, a conjugated lactone ( $\delta$ 116.1), a monosubtituted methyl ( $\delta 14,3,1 \mathrm{x}$ 
Me), a fully substitute benzen ring bearing three oxygen moities $\delta 157,6,109,9,165,6$ $148,4,110,4,107,2)$. These data (Table I) suggested that compound from $C$. soulatri as a new coumarin (soulatro coumarin). A comparison of soulatro coumarin with teymanone (Cao et al., 1998a) showed considerable differencies of both chemical shifts of ${ }^{13} \mathrm{C}$-NMR (Table II).

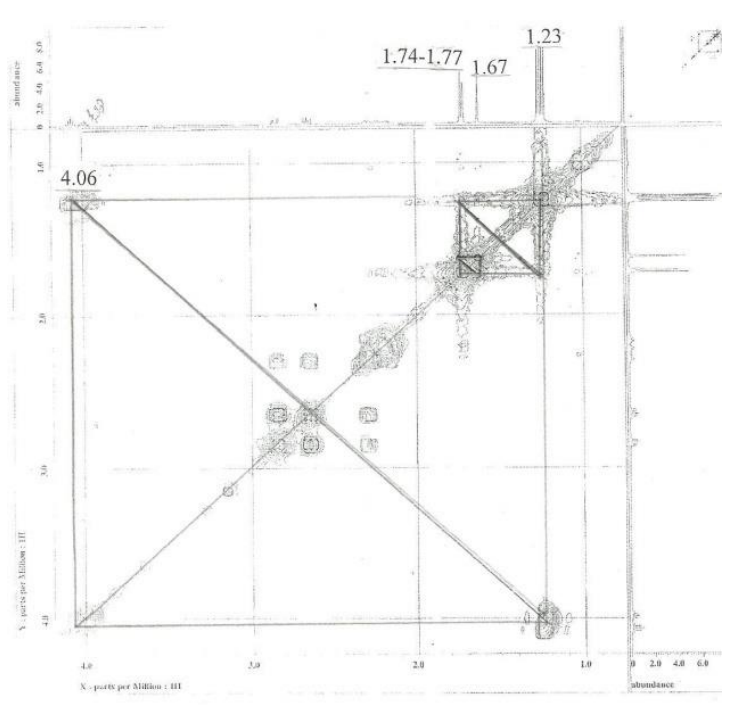

Figure 14. COSY spectrum of new soulatro coumarin compound

The COSY spectrum (Fig. 14) showed the connection of a doublet signal at $\delta 4.06$ and a doublet signal at $\delta 1.23(J=9.2 \mathrm{~Hz})$, other connectivity could be shown between a multiplet signal at $\delta$ 1.74-1.77 and doublet signal at $1.26(J=4,3)$, also other connectivity could be shown between a multiplet signal at $\delta$ 1.74-1.77 and multiplet signal at 1.67

Soulatro coumarin have antiplasmodial activity with inhibiton growth rate of paracites but were not depend of samples concentrations (Table III). Chloroquine was used as positive control (Table IV and Fig. 15) .

Table III. Result of antiplasmodial activity of soulatro coumarin compound as in vivo

\begin{tabular}{ccccccc}
\hline $\begin{array}{c}\text { Soulatro } \\
\text { coumarin } \\
\begin{array}{c}\text { concentration } \\
(\mathbf{m M})\end{array}\end{array}$ & $\begin{array}{c}\text { Mean } \\
\text { DO }\end{array}$ & $\begin{array}{c}\text { Mean } \\
\text { D I }\end{array}$ & $\begin{array}{c}\text { Mean } \\
\text { D2 }\end{array}$ & $\begin{array}{c}\text { Mean } \\
\text { D3 }\end{array}$ & $\begin{array}{c}\text { Mean } \\
\text { D4 }\end{array}$ & \multirow{2}{*}{$\begin{array}{c}\text { Growth } \\
\text { rate (\%) }\end{array}$} \\
\hline 0.0005867 & 3.575 & 5.000 & 4.300 & 4.225 & 4.175 & 100.00 \\
0.005867 & 3.575 & 5.000 & 2.465 & 4.450 & 4.150 & 57.32 \\
0.05867 & 3.575 & 4.100 & 2.725 & 2.900 & 3.150 & 63.37 \\
0.5867 & 3.575 & 3.275 & 1.850 & 3.400 & 4.325 & 43.02 \\
5.8670 & 3.575 & 1.775 & 2.300 & 3.650 & 4.450 & 53.49 \\
58.670 & 3.575 & 2.950 & 2.050 & 2.175 & 3.600 & 47.67 \\
\hline
\end{tabular}

The result of antiplasmodial activity of the sample of soulatro coumarin are recorded in Table III. The sample soulatro coumarin showed activity against $P$. berghei with dosage $0.0005867 \mathrm{mM} / 1 \mathrm{~kg}$ bw; $0.005867 \mathrm{mM} / 1 \mathrm{~kg}$ bw; $0.05867 \mathrm{mM} / 1 \mathrm{~kg}$ bw; $0.5867 \mathrm{mM} / 1 \mathrm{~kg}$ bw
$5.867 \mathrm{mM} / 1 \mathrm{~kg}$ bw and $58.67 \mathrm{mM} / 1 \mathrm{~kg}$ bw could inhibite growth rate of parasite $57.32 \%$; $63.37 \%$; $\quad 43.02 \% ; \quad 53.49 \% ; \quad 47.67 \%$ respectively. Soulatro coumarin shown activity againt Plasmodium berghei, but it is not dose dependent, 
Table IV. Growth rate inhibition of Plasmodium parasite by six dosage of the chloroquine

\begin{tabular}{|c|c|c|c|c|c|c|c|c|}
\hline \multirow{3}{*}{$\begin{array}{c}\text { Cloroquine } \\
\text { Concentratio } \\
n \\
(\mathrm{mM})\end{array}$} & \multicolumn{6}{|c|}{ Parasetemia (\%) } & \multirow{3}{*}{$\begin{array}{c}\text { Growth } \\
\text { rate (\%) } \\
\text { Mean } \\
\text { D2 }\end{array}$} & \multirow{3}{*}{$\begin{array}{c}\mathrm{IC}_{50} \\
(\mathrm{mMol})\end{array}$} \\
\hline & \multirow[b]{2}{*}{ DO } & & Mean & & & Mean & & \\
\hline & & DO & Do & D2 & D2 & D2 & & \\
\hline $3 \times 10^{-7}$ & 0.45 & 0.5 & 0.475 & 3.7 & 4.0 & 3.85 & 100.00 & \\
\hline $3 \times 10^{-6}$ & 0.45 & 0.5 & 0.475 & 2.3 & 2.8 & 2.55 & 66.23 & \\
\hline $3 \times 10^{-5}$ & 0.45 & 0.5 & 0.475 & 0.3 & 0.8 & 0.55 & 14.29 & $3 \times 10^{-6}$ \\
\hline $3 \times 10^{-4}$ & 0.45 & 0.5 & 0.475 & 0.08 & 0.09 & 0.085 & 2.21 & \\
\hline $3 \times 10^{-3}$ & 0.45 & 0.5 & 0.475 & 0.03 & 0.04 & 0.035 & 0.91 & \\
\hline $3 \times 10^{-2}$ & 0.45 & 0.5 & 0.475 & 0.01 & 0 & 0.005 & 0.13 & \\
\hline
\end{tabular}

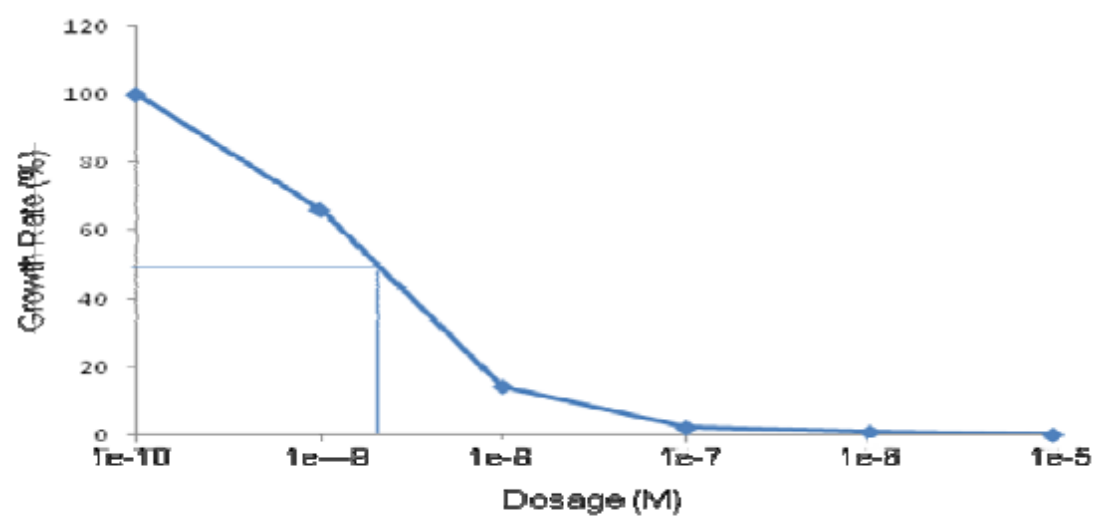

IC so Chloroquine: $3 \times 10^{-9} \mathrm{M}$

Figure 15. Effect of six dosage of chloroquines in growth rate inhibition of Plasmodium parasite (\%)

The chloroquine showed activity against Plamodium with dosage $3 \times 10^{-7}, 3 \times 10^{-6}, 3 \times$ $10^{-5}, 3 \times 10^{-4}, 3 \times 10^{-3}$ and $3 \times 10^{-2}$ could inhibite growth rate of parasite $0 \%$; $33.77 \%$, $85.71 \% ; 97.79 \% ; 99.0 .9 \%$ and $99.87 \%$ respectively. Growth rate inhibition of Plasmodium parasite by chloroquines are depend of dosage of chloroquines. The chloroquine displayed significant inhibition of growth of Plasmodium parasite with $\mathrm{IC}_{50}=3 \mathrm{x}$ $10^{-9} \mathrm{Mol}$ or $=3 \times 10^{-6} \mathrm{mM}$ or $=0,03 \mu \mathrm{M}$, but growth rate inhibition of Plasmodium parasite by soulatro coumarin are note depend of dosage of soulatro coumarin. Chloroquine have shown the best growth rate inhibition of Plasmodium parasite, with $\mathrm{IC}_{50}=3 \times 10^{-9} \mathrm{M}$ or $=0.03 \mu \mathrm{M}$ indicating that chloroquine are the most potent compound compared with benzophenon compounds.

\section{CONCLUSION}

As a conclusion, new soulatro coumarin showed moderate activity on a chloroquinoresistant strain of Plasmodium berghei, The natural approaches developed here to isolate coumarin structures, in association with the biological evaluation, is providing interesting improvement of the antiplasmodial activity. Firstly, the position of the hydroxyl groups at C-5 appears to be important as indicated of activity observed in the present report. Secondly, the substitution by a 1,1dimethylallyl chain, appear to be factors for good activity. So far, the antiplasmodial potency of solatro coumarin correlated well with its ability to inhibit in vivo heme polymerization, suggesting that this compound exerts its antiplasmodial action by preventing hemozoin formation (Ignatuschenko et al., 1997). IC $_{50}$ values were obtained from doupblet experiments.

\section{ACKNOWLEDGEMENT}

Thanks are due to Mr. Ismail Rahman at the Herbarium Bogoriences - LIPI Bogor for identifying the plant material. The authors are grateful to Puji at Eijkman Institute for bioassay and Sofa Fajriah for the NMR measurement and Puspa Dewi for MS measurement. 


\section{REFERENCES}

Abbas, J., 2008, Doctoral Disertation, Isolation and structure elucidation biological active compound from $C$. soulattrii Burm. F., C. incrasaptum M. R. Henderson and Wyatt Smith and $C$. tomentosum Wright., University of Indonesia.

Abbas. J., Hanafi.M., Kardono L.B.S., Que-Wei Qin., Kosela S, 2009, Cytotoic coumarin from Calophyllum Incrasaptum M.R Henderson \& WyattSmith (Guttiferae). International Journal of Applied Chemistry, 4(3), 205-208.

Abbas. J., M. Hanafi., Kardono L.B.S., 2009, Antioksidant activity of coumarin compound from stem bark of Calophyllum incrasaptum. Proceeding of Natural Products Simposium XIV. Natural Products resources as well known for treatment of Cancer. BPPT Jakarta 2009 August, I I-I2.ISBN : 978-602-959।I-0-I

Abbas. J., Nina Artanti, Syafruddin, M. Hanafi, 2009. Antimalarial Activity of Some Plants Traditionally Used in Treatment of Malaria in Indonesia.Proceding Chemistry Seminar XVIII. Santika Hohel, Yogyakarta, Desember 32009, ISSN: 0854-4778

Akhouri, R.R., Sharma, A.S., Malhota, P. and Sharma, A., 2008, Role of Plasmodium falciparum thrombospondin-related anomymous protein in Host-cell interactions, Malarial Journal, 7(63), III.

Ampofo, S.A. and Waterman, P.G., 1986, Xanthones and neoflavonoids from two Asian species of Calophyllum, Phytochemistry, 25(II), 26I7-2620.

Bennett, G.J. and Lee, H.H., 1988, Xanthones from Guttiferae. Phytochemistry, 28(4), 967-998.

Cao, S.G., Sim, K.W., Pereira, J. and Goh, S-H, 1998a, Coumarins from Calophyllum teysmannii, Phytochemistry, 47(6), I05I1055.

Cao, S.G., Wu, X.H., Sim, Tan, Benny, K.Y., Vittal Jagadese. J.J., Perera. J.T. and Go. S-H., 1998b, Minor coumarins from Calophyllum teysmannii var inophylloide and synthesis of cytotoxic calanone derivates, Helvetica Chimica Acta Phytochemistry, 47(6), I05I-I 055.

Crane, S., Aurore, G., Joseph, H., Mouloungui, Z. and Bourgeois, P., 2005, Composition of Fatty Acids Triacylglycerols and Unsaponifiable Matter in Calophyllum calaba L. Oil from Guadeloupe, Phytochemistry, 66, |825-I83I.

Dharmaratne, H.R.W., Nishanthi, W.M. and Wijesinghe, 1997, Trioxygenated Diprenylated Chromenxanthone from Calophyllum Moonii, Phytochemistry, 46(7), 1293-1295.

Dharmaratne, H.R.W., Sotheeswaran, S.,Balasubramaniam, S., 1984, Triterpenes and Neoflavonoids of Calophyllum lankaesis and Calophyllum thwaitesii, 23(II), 260I-2603.

Dharmaratne, H.R.W., Perera, D.S.M., Marasinghe, G.P.K. and Jamie, 1999, A chromene acid from Calophyllum cordato-oblongum, Phytochemistry, I5, III-II3.

Fotie, J., Nkkengfack, A.E., Rukunga, G., Tolo, F., Peter, M.G., Heydenreich, M. and Fomum, Z.T., 2003, In vivo antimalarial activity of some oxygenated xanthones, Annals of Tropical Medicine and Parasitology, 97(7), 683-688.

Fotie, J., Nkkengfack, A.E., Rukunga, G., Tolo, F., Peter, M.G., Heydenreich, M., Fomum, Z.T., 2003, In vivo antimalarial activity of some oxygenated xanthones, Annals of Tropical Medicine and Parasitology, 97(7), 683-688.

Guilet, D., Seraphin, D., Rondeau, D., Richommme, P. and Bruneton, J., 2001, Cytotoxic coumarin from Calophyllum dispar, Phytochemistry, 58, 57I-575.

Gustafon, K.R., Bokesch, H.R., Fuller, R.W., Cardellina, J.H., Kadushin, M.R., Soejarto, D.D. and Boyd, M.R., 1994, Calanone A Novel Coumarin From Calophyllum teysmannii, Tetrahedron Lettres, 35(32), 582I-5824.

Hay, A.E., He'lesbeux, J-J., Duval, O., LabaRed, M., Grellier, P. and Richomme, P., 2004, Antimalarial xanthones from Calophyllum caledonicum and Garcinia vieillardii, Life Sciences, 75, 3077-3085.

Ignatuschenko, M.V., Winter, R.W., Bachinger, H.P., Hinrichs, D.J., Riscoe, M.K., 1997, 
Xanthones as antimalarial agents: studies of a possible mode of action. FEBS Letters, 409, 67-73.

Ito C., Itoigawa, M., Mishina, Y., Filho, C.V., Enjo, F., Tokuda, H., Nishino, H. and Furukawa, H., 2003, Chemical consttuent of Calophyllum brasiliense: Structure of the three new coumarin and cancer chemopreventive activity of 4-subtituted coumarin, Phytomedicine, 66(3), 369-37I.

Khan, M.R., Kihara, M., Omoloso. A.D., 2002, Antimicrobial activity of Calophyllum soulattri, Fitoterapia, 73, 74I-743.

Kijjoa, A., Gonzales, M., Afonso, C.M., Pinto, M., Anantachoke, C. and Herz, 2000, Xanthon from Calophyllum teysmannii var. Inophylloide, Phytochemistry, 53, 833-836.

Krungkrai, S.R., 200I, Activity of some oxygenated xanthones, Annals of Tropical Medicine and Parasitology, 97(7), 683-688.
Limuna, M., Tosa, H., Tanaka, T. and Yonemori, S., 1993, Two xanthones from root bark of Calophyllum inophyllum, Phytoochemistry, 35(7), 527532.

Reyes-Chilpa., Estrada-Muniz, Apan, Amekraz., Aumelas., Christopher and Jankowski., Vazquez-Torres, 2004, Cytotoxic effects of mammea type coumarins from Calophyllum brasiliense, Life Science, 75, 1635-1647.

Samarawera., Ravelanjato, B. and Kuneneshch, N., 1983, Pyranocoumarin from the stem bark and leaves of C. Soulattri, Phytochemistry, 26( I I), 2973- 2987.

Soerianegara and Lemmens, R.H.M.J., 1994, Plant Resources of South-East Asia, Timber trees mayor commercial timbers, Bogor, Indonesia, Prosea, 5(I), II4-132.

Trager, W. and Jensen, J.B., 1976, Human malarial parasites in continuous culture, Science, 193, 673-677. 